\title{
Banal Nationalism Disputes in Venezuela: 1999-2019
}

\author{
Gabriel Andrade \\ Ajman University
}

\begin{abstract}
Michael Billig's idea of "banal nationalism" is a useful concept to approach a frequently neglected aspect of Venezuelan political disputes in the past 20 years. In Billig's formulation, banal nationalism is the constant reaffirmation of a nation's identity, through the display of national symbols. After Hugo Chavez rose to power, there were changes to Venezuela's flag, coat of arms, and banknotes. This aroused disputes that served as a micro-cosmos of Venezuela's larger confrontation. This article reviews the disputes over the changes made to those national symbols. It concludes that, although political and economic issues are at stake in Venezuela's current crisis, there are also ongoing culture wars. In that sense, an analysis of Venezuela's recent crisis would be incomplete without a consideration of its banal nationalism disputes.
\end{abstract}

\section{Keywords}

Banal nationalism; Venezuela; Flag; Coat of arms; Banknotes

\section{Introduction: what is banal nationalism?}

Latin American nations are relatively new, at least when compared with the older nation-States of Europe. Most were only formed in the 19th century, as they gained independence from the Spanish and Portuguese empires. We may be tempted to think that, as a result, in Latin America, nationalism is not a particularly strong ideology, given that there is not much historical depth that nationalists can appeal to.

However, it was nationalism itself that launched the revolutionary wars that led to independence, and created wholesome new nations. In these emerging countries, nationalism may not have had the ethnic, blood-and-soil component that was typical of European nationalism, but they did have the civic element to national unity.

As famously explained by Benedict Anderson in Imagined Communities, Latin American nationalism foreshadowed the type of nationalism that

\footnotetext{
* Gabriel Andrade, Ajman University, Ajman, United Arab Emirates, +971-54456-2552; gabrielernesto2000@gmail.com.
} 
would later follow in Africa and Asia. Emerging nations would not be built so much on narratives of shared blood, but rather, on a shared experience of imperial oppression. As Anderson (2006) posits, "neither economic interest, Liberalism, nor Enlightenment could, or did, create in themselves the kind, or shape, of imagined community to be defended from these [imperial] regimes" depredations; to put it another way, none provided the framework of a new consciousness - the scarcely seen periphery of its vision - as opposed to center-field objects of its admiration or disgust. In accomplishing this specific task, pilgrim Creole functionaries and provincial Creole printmen played the decisive historic role" (p. 65).

Latin-American nationalism has been more civic, meaning that the nation is made up of its citizens, regardless of their origin. By contrast, ethnic nationalism, the kind that is more prevalent in Europe (most notably, in regions such as the Balkans), has traditionally been more aggressive. But that does not necessarily mean that nationalism is less salient in Latin America, or for that matter, more beneficial.

We may very well argue that, in Latin America, there also prevails banal nationalism. This concept, originally formulated by Michael Billig (1995) in his influential book Banal Nationalism, can be defined thus: "the ideological habits which enable the established nations of the West to be reproduced. It is argued that these habits are not removed from everyday life, as some observers have supposed. Daily, the nation is indicated, or "Alagged", in the lives of the citizenry. Nationalism, far from being an intermittent mood in established nations, is the endemic condition" (p. 6).

Billig's description of nationalist dynamics may be interpreted as an interesting challenge to Marxist notions of history. As opposed to the conventional materialist Marxist interpretation of History that focuses on infrastructural factors (Aronwitz, 2016), Billig's theory of nationalism allows for the importance of symbolic dimensions in human action. Disputes over flags, anthems, or banknotes can be far more intense than disputes about wages or labor conditions. Nationalism has played a role in this regard, and it must not be underestimated as a simple "'bourgeois concern'." Instead, Billig's work indicates that these disputes are usually at the core of priorities in most societies.

Indeed, this sensitivity to the power of symbols in human action turned out to be a fundamental aspect of 20th-century anthropology, which informs much scholarship on the dynamics of nationalism. As the theoretical influence of Marxism began to wane, new emerging culturalist paradigms took prominence. For example, Marshall Sahlins' (2013) critique of “"practical 
reason" and his emphasis on the cultural dimension of many aspects of human behavior offer a stronger theoretical background to understand why the particular colors of a flag can arouse so much tension and debate in many countries. Likewise, the work of Victor Turner (1975) is landmark in this regard: Turner's emphasis on the importance of symbols when doing anthropological studies provides a firm basis to approach the cultural importance of national anthems, banknotes, flags, and so on, in the study of nationalism. In his studies of modern nationalism, Ernest Gellner (1991) has also supplied an important theoretical understanding of how symbols become a central aspect of emerging nationalist identities.

These descriptions fit Latin-American nations quite well. Each of these nations has to remind their citizens as to who they are, in national terms. This is frequently done through the constant reproduction of symbols. This kind of nationalism is "banal," in the sense that it does not seek deep ethnic roots; but Billig himself makes the case that this sort of nationalism is nevertheless relevant, as apparently trivial things such as the flag, carry on deep meanings, and can even be sources of disputes with major social consequences.

In this article, I shall analyze how banal nationalism has become a point of contention in Venezuela, for the past 20 years. Ever since Hugo Chavez rose to power in 1999, Venezuela has been immersed in a deep climate of political polarization. My working hypothesis will be that, as a result of this political polarization, banal nationalism disputes have been increasingly intense. This, amongst other things, led to a societal collapse, which in turn led to a humanitarian crisis that is far from being solved (Grillet et al., 2019). Banal nationalism was not the cause of these events, but it certainly serves as a reflection of the ideological clashes that have been going on for the past two decades. Disputes over the flag, the coat of arms, and banknotes serve as illustration of the broader conflict that has driven Venezuela to its current lamentable situation. For this reason, any analysis of the history of Venezuela in the past 20 years would be incomplete without a consideration of its banal nationalism disputes. In what follows, I will use a methodology of documentary revision to highlight recent events, so as to address the formulation of the initial hypothesis regarding banal nationalism.

\section{Disputes over the flag}

Flags are the quintessential element of banal nationalism. As Billig (1995) himself argues, "the central thesis of this book is that, in the established nations, there is a continual 'flagging', or reminding of nationhood $\square$ The metonymic image of banal nationalism is not a flag which is being consciously 
waved with fervent passion; it is the flag hanging unnoticed in the public building" (p. 8).

In many cases, flags are far from being mere pieces of cloth. They may be objects that people take as worth dying for, often literally. Tim Marshall (2016) makes this point in the aptly titled book Worth Dying For: "What does it mean to try to encapsulate a nation in a flag? It means trying to unite a population behind a homogeneous set of ideals, aims, history and beliefs - an almost impossible task. But when passions are aroused, when the banner of an enemy is flying high, that's when people flock to their own symbol. Flags have much to do with our traditional tribal tendencies and notions of identity - the idea of 'us versus them"' (p. 5).

The flag of Venezuela has had various transformations throughout its history. Conventional historians accept that the original design goes back to Francisco de Miranda's revolutionary expedition in 1801 (Traver, 2018). Miranda had been active in the French revolutionary wars. In those campaigns, the republican tricolor had replaced the monarchical fleur de lis (Olins, 1979). As the French Revolution inspired similar movements in other parts of the world, tricolor patterns became commonplace in revolutionary movements, and Venezuela was no exception.

In his first expedition, Miranda chose red, yellow, and blue; apparently, he was impressed by Goethe's explanation that those are the primary colors of the spectrum, and Miranda seemed to think that such characteristics would be very fitting for the flag of an emerging nation (Smith, 1975). Yet, in a subsequent expedition, Miranda chose black, red, and yellow. Although those expeditions were failures and Miranda was driven to exile in London, he later on managed to return to Venezuela in 1810 to play a prominent role in what came to be known as the First Republic (or, given its short-lived duration, some historians call it the patria boba, the foolish fatherland) (Altez, 2006).

As an honor to Miranda's pioneering role, his original colors (yellow, blue, and red) were embraced as the colors of the national flag in the First Republic. Additionally, in the yellow ribbon, it displayed an image of an indigenous woman, a crocodile, and the Caribbean Sea. Although Miranda had originally chosen those colors given their primacy in the spectrum, Venezuelan nationalism went on to rationalize these colors as follows: yellow represents Venezuela's riches, blue represents its location in the Caribbean Sea, and red represents the blood spilled by soldiers in the wars of independence. This goes on to prove that, in nationalism, there are plenty of arbitrary elements that are only rationalized a posteriori (Hastings, 1997). 
Patriotas (as the proponents of independence were known) retook Caracas in 1813, and formed what came to be known as the Second Republic. This time, they embraced a flag that was designed with a red field and a white rhombus encasing a black rectangle. This Second Republic was also short-lived, and by 1814, loyalists to Spain had retaken Caracas.

Although they did not take back Caracas, patriotas reassembled in exile, and adopted a new flag for their movement in 1817. This time, it followed Miranda's original pattern of yellow, blue, and red, but the images of the first flag were removed. In its place, seven horizontal blue stars were placed, depicting the seven Venezuelan provinces that originally rebelled against Spanish rule in 1811, and had formed the First Republic.

Patriotas then made their way to Venezuela, but still did not take Caracas back. Instead, they settled in Angostura, and while there, in late 1817, modified the flag to add an eight star, this time representing the province of Guayana (where Angostura is located), which had originally not been part of the coalition of provinces seceding from Spain.

Once liberated from Spanish rule, Venezuela was incorporated into Gran Colombia in 1819. Continuing to honor Miranda's original design, Gran Colombia adopted the tricolor flag, this time with a coat of arms on the yellow ribbon. Then, in 1821, a new coat of arms was adopted, but this time it was placed on the blue ribbon.

By 1830, Venezuela had seceded from Gran Colombia. Its flag remained basically the same, but instead of using Gran Colombia's coat of arms, it incorporated a newly formed Venezuelan coat of arms, placed on the blue ribbon. In 1836, the coat of arms was modified and placed in the yellow ribbon. Then in 1859 , for a short period of time, the flag went back to the first 1817 design (tricolor with seven blue stars on the yellow ribbon); then that same year, the flag was made to bear 20 stars.

In 1863, once again it was redesigned: this time, it would have seven stars in a circular shape in the central blue ribbon. There were minor changes in the design in the ensuing years, and then, one further important modification was added in 1930: it now incorporated the seven stars, but in a semicircular shape.

By the time Hugo Chavez was elected as President in 1998, this was the design. As can be appreciated from this brief history, the Venezuelan flag has undergone continuous transformations. This dynamic reflects the country's chaotic history of caudillismo in the 19th century (Saez, 2015). Almost every time a new caudillo would appear on the scene, he attempted to eradicate his 
predecessor's imprint in public symbols, and sought to redesign the flag, so as to leave his own symbolic mark.

The fact that the flag design was finally stabilized by 1930 is not circumstantial. This coincides with Juan Vicente Gomez's tenure. Gomez is widely recognized by scholars as the last of the caudillos in Venezuelan history, and the first modernizer who, despite his brutality, gave the country a good dose of stability (Perdomo, 2007). After him, the flag would remain unchanged for a long period of time.

In the view of many analysts, Chavez was a 21 st-century caudillo-like figure (Carrasquero, 2010; Encarnacion, 2016; Carbo, 2012). His populist style widely appealed to the impoverished masses, and he reached power under an electoral platform of radical change, which would come to be self-styled as the "Bolivarian Revolution." It comes as no surprise, then, that Chavez followed the pattern of many 19th-century caudillos, in placing great energies into changes of national symbols, so as to leave his own mark in history.

Even before the election of Hugo Chavez as President, there were already some disputes about Venezuela's National Anthem. For example, in 1997, famed Venezuelan singer Ilan Chester popularized a version of the Venezuelan National Anthem that was perceived as being too embedded in pop musical tendencies. This controversy never developed into a full political debate, but by 2006, at Chavez's instigation, Parliament passed the Ley de Bandera Nacional, Himno Nacional y Escudo de Armas de la República Bolivariana de Venezuela (Law of the National Flag, National Anthem, and Coat of Arms of the Bolivarian Republic of Venezuela). This included a provision to establish the flag as having eight stars. This occasioned the first major dispute of banal nationalism in this period.

Critics pointed out that Chavez was behaving like a megalomaniac bent on changing everything, incurring huge unnecessary public expenses (Toro, 2013), as the recall of old flags, and the distribution of new flags, came with considerable economic cost.

Yet, probably as opposed to any previous Venezuelan President in the 20th century, Chavez had a deep sense of historical awareness, and he countered that the seven-star flag was a major injustice and distortion of Venezuela's history, and this needed to be corrected, no matter the financial cost (Heydra, 2003). Guayana, so he claimed, had been unfairly excluded from Venezuela's flag. It was true that, in the First Republic, Guayana had not been amongst the provinces that had chosen to break with Spanish rule, but by 1817 it was the headquarters of the provisional government that would go on to complete 
Venezuela's independence. Recall that in 1817, the flag itself had eight stars, as recognition of this fact.

In the subsequent periods of the 19th century, caudillos played with the number of stars (the 1859 version included 20 stars, reflecting the newly organized territory of the nation, comprising 20 States) and it was finally settled at seven. Chavez felt (or so he claimed) a historical mission to reinstitute Guayana as one of the provinces that fought hard for independence. This decision morphed into a big dispute, but the historical technicalities of the issue became moot.

Chavez had emerged as an extremely polarizing figure, both at home and abroad. In 2002, the opposition was mobilized, and in April, managed to drive Chavez out of office in a short-lived coup (Cannon, 2004). Then, in early 2003, there was a massive oil strike that jeopardized Chavez's grip on power, but that ultimately also failed (Hawkins, 2003). During these events, demonstrators massively embraced the national flag (still with seven stars). Ultimately, the flag became a powerful symbol for the opposition.

This became a threat to Chavez's power, as the main symbol of banal nationalism was fully appropriated by the opposition. This may also partly explain why Chavez was so eager to modify the flag. By adopting an eightstar flag, he took a step forward and this move allowed him to recapture the symbolism that, a few years prior, had been taken away from him. By designing a new flag (if only merely with one additional star) and massively promoting it in public ceremonies starting in 2006, Chavez was able to make the flag once again a representation of loyalty to his government.

In turn, the opposition refused to let go of the power of the flag, but it also seized the opportunity to draw symbolic battle lines. While on an official level, opposition figures had to accept an eight-star flag (otherwise, they risked being prosecuted, as it would be an offence under the 2006 law), street protests embraced the seven-star flag. After Chavez's death in 2013, the humanitarian crisis prompted Venezuelans to massively migrate, and the Venezuelan diaspora abroad (overwhelmingly unsympathetic to Chavez's legacy) had embraced the seven-star flag.

As mentioned above, the dispute had nothing to do with whether or not Guayana deserved representation as the eighth province in the flag. Common Venezuelans do feel pride for Simon Bolivar and his quest for emancipation, but very few of them are sufficiently versed in the detailed technicalities of Venezuela's complex history in the 19th century. What the eighth star truly represents is the legacy of Chavez, and that is what is at stake in this dispute. Although leading opposition figures, such as Juan Guaido (recognized as 
legitimate presidents by a considerable number of countries in 2019), have hinted that, were they to gain power, the flag would preserve its eighth star, common people hoping for a change of government (especially those in the diaspora) still prefer the seven-star flag, and in fact consider the eight-star flag as a symbol of oppression.

In the 2012 campaign for the Presidential election, opposition leader Henrique Capriles once again brought the flag disputes to the front (Garcia and Lozano, 2012). Electoral law in Venezuela forbids the use of flags in electoral campaigns, presumably so as to prevent candidates from appropriating symbols that belong to all Venezuelans. But, given that Chavez had disregarded this regulation in his own campaign, Capriles embraced the flag in his campaign, but took it a step further: he began wearing a baseball cap depicting the flag. This cap had eight stars. But, given that at the time, the opposition once again was able to claim the flag (temporarily forgetting about the dispute over the number of stars), Chavez's regime had to come up with a new way of reclaiming the flag for their own.

They did so by designing baseball caps depicting this flag, but the text "4F" was printed in red over the yellow or blue band. This $4 \mathrm{~F}$ refers to February 4 , 1992, the date when Hugo Chavez attempted a military coup and entered the political scenery. Although this move never affected flags (only baseball caps), it turned out to be yet another dispute as to which flag was truly representative of Venezuelans: with, or without the "4F" text. As opposed to the eight-star flag, this time, it was easy for the opposition to reject the innovation. In the case of the eight-star flag, some people in the opposition acknowledged that it was fair to include Guayana, and that in fact, the 1817 flag included eight stars; but in the case of " $4 \mathrm{~F}$," it was a clear reference to an illegitimate and needlessly bloody military coup.

The 2014 protests in Venezuela also witnessed a renewed dispute over flags. That movement, known as "La salida" ("The exit"), was led by Leopoldo Lopez, and involved heavy involvement by students who demanded Nicolas Maduro's (Chavez's hand-picked successor) resignation (Alvarez-Muro, 2016). The movement eventually turned violent, but government repression was even more violent, leaving an atrocious death toll in a short period of time.

As students were becoming radicalized, they rejected the peaceful approach that hitherto had been favored by opposition leaders such as Capriles. As part of this radicalization, they embraced the flag of the Second Republic (a red field, and a white rhombus encasing a black rectangle). The Second Republic came into being after Simon Bolivar completed the so-called Admirable Campaign, in a series of battles on a trail to Caracas. In this trail, Bolivar emitted his 
infamous Decree of War to the Death, which warned Spaniards that if they did not join his side in the war, they would be executed even if they were innocent (Kohan, 2013). The violent context of the Second Republic appealed to students, who embraced that flag. However, as the movement has died out, that particular flag has lost appeal, and for now, the opposition still clings to the seven-star version, whereas the more pragmatic leaders (such as Guaido) realize that it is impossible to turn back many of Chavez's transformations, so they simply accept the eight-star flag, as Capriles did in 2013.

\section{Disputes over the coat of arms}

Historically, coats of arms antecede flags in the formation of national identities. As Tim Marshall (2016) recounts the history of flags and heraldry, "symbols would develop into a fully fledged system of heraldry with coats of arms, and it was within this that an entire complicated catalogue of rules governing flags took form: what shape, what colour, when and where they should be flown, in what order, and so on" (p. 73) Consequently, although not as important as flags, coats of arms also form part of banal nationalism, one important reason being that, as opposed to flags, coats of arms offer greater opportunities for more elaborate symbolism.

Just as in the flag, the coat of arms in Venezuela has also gone through some transformations, although not as numerous as in the case of the flag. When the First Republic was established in 1811, a coat of arms was designed; it incorporated the seven stars in a circular shape, and it commemorated the year 1811.

For the Second Republic (1812) the coat was modified. This time it had a condor: in its left claw, it held a caduceus with a Phrygian hat (an ancient symbol of freedom), and in its right claw it held seven arrows, once again representing the seven provinces. For the Third Republic (1814), the coat of arms was very similar to the emblem that had been used in the flag of the First Republic: it depicted the Caribbean Sea, a crocodile, and an indigenous person, but this time it was a man.

Gran Colombia used that same coat of arms, but slightly modified it, and then significantly modified it in 1821, replacing it with horns of plenty and the Roman fasces. When Venezuela seceded in 1830, it retained that same coat of arms but added the text, "Republic of Venezuela."

Then, in 1864, it was again completely redesigned. It incorporated horns of plenty on top; in the upper compartments it depicted 20 wheat ears (representing the newly formed 20 States) and a set of arms with the flag. In the lower part, it depicted a horse galloping toward the right. On the sides, 
there were two leaves. Underneath, two dates were commemorated: July 5 , 1811 (the declaration of independence) and March 28, 1864 (the approval date for the Constitution of 1864). The motto "God and federation" was likewise included.

This imagery was preserved for almost a century. In 1954, there were a few slight changes. The horse now continued to gallop toward the right, but its head turned toward the left. The motto "God and federation" was removed, and in its place, "Republic of Venezuela" was inscribed. Likewise, the date March 28, 1864 was replaced with February 20, 1859 (the declaration of a federal model for Venezuela).

The 2006 law regarding national symbols also stipulated changes in the coat of arms. The label "Republic of Venezuela" was changed to "Bolivarian Republic of Venezuela." In 1999, Chavez moved forward a national constituency, with the task of writing a new constitution. This new constitution changed the name of the country to "Bolivarian Republic of Venezuela," in honor of Simon Bolivar. At the time, it elicited strong reactions in the opposition (La Nacion, 2013), as many felt that this change of name implied a heavy doctrinal load. In fact, when Chavez was removed temporarily from power for merely 48 hours in 2002, the then-designated President Pedro Carmona Estanga decreed that the official name of the country would revert back to "Republic of Venezuela" (Plessman, 2002).

Given that the coup was short-lived, and Carmona Estanga's decrees became an embarrassment on account of his authoritarian approach, the issue over the official name of the country ceased to be a dispute; the opposition simply accepted that the country had a new name. So, when the 2006 law changed the inscription on the coat of arms to "Bolivarian Republic of Venezuela," there was no quarrel.

Interestingly, Chavez made no attempt to change the commemoration of dates in the coat of arms, even though February 4, 1992 was constantly celebrated by the State's propaganda apparatus. Yet, Chavez did opt to modify the depiction of the horse, and unlike the change in the inscription regarding the name of the country, this did elicit a new dispute.

When the horse was first introduced in the 1864 coat of arms, it galloped toward the right, without turning its head. By Chavez's own recounting, his youngest daughter noticed that the 1954 version of the coat of arms was weird, because the horse was turning its head toward the left, as if it were looking backwards (Torres, 2009: 209). This seemed strange, as horses typically do not do that. 
Banal Nationalism Disputes in Venezuela: 1999-2019

So, on the basis of his daughter's suggestion, Chavez proposed to depict a horse in a natural pose, just as the 1864 version did. But crucially, Chavez seized the opportunity to change the direction of the horse. In 1864, the horse galloped toward the right. Chavez insisted that the horse should gallop toward the left. As it turned out, this became a hugely significant move.

When Chavez entered the political scene in 1992, he was a completely unknown figure. Few people knew who he was, or what he stood for. His ideology was far from clear, and many saw him as yet one more right-wing military authoritarian figure, which had been all too typical in Latin America in the previous decades (Weyland, 2013).

By 1998 , Chavez ran his campaign on a promise to wipe out corruption, and impose order, two very typical promises of right-wing authoritarian regimes in the region. But he had been approaching Fidel Castro. For the 1998 election, Chavez explicitly told journalists that he believed Cuba was a dictatorship, and he was not seeking socialist policies, such as massive nationalizations (Ramos, 2016). At most, he sought to favor a "third way," a la Tony Blair (Pabian, 2008).

Yet, by 2006, the pretense was over. Chavez had signed oil deals hugely favorable to Cuba, and had accepted the massive influence of Cuban advisors. He had also begun more aggressive policies of wealth redistribution, and no longer had qualms about nationalizing industries and exercising tight controls over the economy.

And so, as if to leave no doubts about his ideological shift, he seized the opportunity to change the horse's direction toward the left. He did not go so far as to claim that this change of direction was because the country ought to be leftist in ideology. He simply claimed that horses do not turn their heads when they gallop; but in a few words, he sent a clear message: he was a man of the left, and he was not going to pretend otherwise any longer.

Predictably, this move also aroused disputes coming from the opposition. Chavez's move was viewed as the caprice of a megalomaniac. It appeared that a little child, such as Chavez's own daughter, had more power over anyone else in the representation of national identity. It seemed as if Chavez's decision went on to prove that he did have strong authoritarian leanings; after all, this was the sort of thing dictators would do. Saddam Hussein (whom Chavez enthusiastically embraced as an ally and friend) placed "God is great" on the Iraqi flag, coming from his own handwriting (Podeh, 2011), and Chavez seemed to be doing something similar. 
Of course, the law was passed by the National Assembly. But it clearly had come from an initiative that originated in Chavez's own daughter. To Chavez's detractors, this seemed to prove that the National Assembly was just a puppet of executive power, whose members would even bow to the caprices of the leader's child.

But what really struck a nerve was the leftist orientation of the horse. The opposition was upset that the official national symbols had become partisan, and that Venezuela had now unashamedly embarked on a path of leftist ideology, which seemed to exclude large portions of the population that did not sympathize with leftist ideas.

Given that, as opposed to flags, it is not as practical to display coats of arms in manifestations, ultimately, the dispute over the horse died down. Venezuelans in the opposition are divided about the number of stars the flag should have, but when it comes to the coat of arms, most accept the horse galloping toward the left as a fait accompli.

Yet, the coat of arms has given occasion to a new dispute. Very soon after Chavez's death in 2013, Venezuela's economy collapsed. Scarcity spread throughout the country, and Venezuelans had to endure long breadlines, something seldom experienced in the country's history.

In the face of this, anonymous protesters designed a new coat of arms. The horns of plenty were completely empty. The leaves on the sides were dried out. The wheat ears were likewise not leafy. And most remarkably, the horse was positioned toward the left, but it was not galloping, and its aspect was pathetic: it was visibly tired and underweight, to the point that its ribs were visible.

This was a very creative piece of artwork, made out to represent how Chavez and Maduro's failed policies had driven the country to ruin, thus impoverishing the once robust symbols of the coat of arms. This version of the coat of arms was widely circulated in the opposition, and occasionally displayed in anti-government manifestations.

Analysts have noted how, in the period of Venezuelan history that began with Chavez, conspiracy-mongering has been constant (Andrade, 2019). When it came to the parody of the coat of arms, President Maduro proposed a new conspiracy theory. According to him, the coat of arms parody was designed in Colombia as part of a propaganda war against Venezuela (Alba Ciudad, 2015). Maduro never provided empirical evidence for his claim, and in fact that attitude only confirmed the argument that, in failing to understand why people were upset, Maduro refused to acknowledge that this new coat 
of arms would come from Venezuelans' own creativity, when faced with dire economic conditions.

The 2006 law stipulates that any form of disrespect toward the flag, the coat of arms, or the national anthem ought to be punished with fines. The parody of the new coat of arms would seemingly fall under this stipulation, and opposition leaders never dared to openly support the designers of the parody. Venezuela's liberal tradition is not yet strong enough, so as to grant rights for the burning or desecration of the flag, as opposed to what happens in the United States (Welch and Bryan, 1996).

However, the dispute over the parody of the coat of arms did serve as an occasion to begin this discussion in Venezuela, although never in the open public. Occasionally, protesters also wave the flag (either with seven or with stars) upside down, as a form of protest. Some hardcore government officials also see this as a punishable offense. In turn, these disputes have opened (if only informally) the conversation about whether or not there should even be a law that penalizes flag desecration.

\section{Disputes over banknotes}

In his description of banal nationalism, Billig (1995) writes: "Flags are not the only symbols of modern statehood. Coins and banknotes typically bear national emblems, which remain unnoticed in daily financial transactions. Naming the unit of currency can be a highly symbolic and controversial business, especially in the early days of a nation" (p. 41).

The name of the unit of currency in Venezuela is not in dispute. Ever since his remains were repatriated to Venezuela in 1842, Simon Bolivar has remained an undisputed symbol of national unit, to the point that, as Carrera Damas (2003) has extensively documented, there has been a cult to his figure. So, in regard to Bolivar as the name of the national currency, all Venezuelans are happy to have it.

However, the dispute is over what image of Bolivar ought to be used in banknotes. Chavez rose to power as a self-proclaimed Bolivarian. He tried to present himself as a modern-day Bolivar who would once again liberate Venezuela from the oppression of aristocracies (Arreaza, 2003). Yet, inasmuch as the cult of Bolivar permeates throughout Venezuelan political culture, the opposition has also claimed Bolivar's legacy.

Eventually, Chavez came to realize that appealing to Bolivar was not enough to rally support and mark a difference with other politicians. He needed an additional symbol that would set him apart. In 2010, he found it. Chavez 
had been defending the conspiracy theory that Bolivar did not die of natural causes, but rather, was killed by American and Colombian agents (Andrade, 2019). This eventually became another banal nationalism dispute, for it raised a bigger question about what Bolivar stood for. If, as Chavez insisted, Bolivar was murdered by American agents, then that would serve Chavez's purpose of using Bolivar as a symbol of anti-American anti-imperialism, and in that regard, Chavez would use Bolivar to his favor in his version of banal nationalism. In order to attempt to prove his theory, he ordered the exhumation of Bolivar's remains, so as to do some forensic exams. There were no conclusive results about whether or not Bolivar was poisoned.

That occasion also provided the opportunity to reconstruct Bolivar's facial features. And so, on the basis of a forensic modeling, a team of scientists produced a very realistic photographic image of Bolivar (Angosto-Fernandez, 2016). Traditionally, banknotes were printed with 19th-century paintings of Bolivar, but starting in 2011, they were printed with the reconstructed realistic image of Bolivar.

This aroused a new dispute. Opposition leaders argued that Bolivar's dignity had been disrespected with the exhumation. However, the main point of dispute was that, according to critics, the new image of Bolivar appeared to be suspiciously similar to Chavez himself (Linongi, 2016). Bolivar himself had testified that an 1824 portrait by the Peruvian painter, Jose Gil de Castro, was the most accurate (Mejia, 2012). That painting did not greatly resemble the reconstructed image promoted by Chavez.

One prominent opposition leader, Henry Ramos Allup, added racial overtones to the dispute. He claimed that the image of Bolivar promoted by Chavez had some "mulatto-like" features (Avendano, 2017), when in fact, Bolivar was a full-blooded criollo of Spanish descent. Chavez always presented himself as a zambo (a person of Indian and African descent), and his political message did on occasion appeal to racial differences, rallying support from Venezuela's mixed-race majority. So, in the view of Ramos Allup and other opposition leaders, Chavez was cynically using Bolivar's image so as to once again appeal to race, and by doing so, he was distorting history and disrespecting Bolivar himself. In fact, when Ramos Allup was elected as President of the National Assembly in 2016, one of his first deeds was to remove Bolivar's reconstructed images from the National Assembly venue, and replace it with the traditional paintings that were displayed before the exhumation (Telesur, 2016).

There were other disputes regarding banknotes. Prior to Chavez's rise, alongside Bolivar, banknotes included other heroes from Venezuela's War of Independence. The most significant of these heroes was Jose Antonio Paez 
(Queipo et al., 2017). His image appeared on numerous banknotes. Paez had been a fierce llanero fighter who joined forces with Bolivar. Together, they launched successful military campaigns that ultimately resulted in the defeat of the Spanish empire in Venezuela.

Yet, by 1830, Paez and Bolivar had become enemies. Paez was the main architect of Venezuela's secession from Gran Colombia (Bolivar's own project). He then went on to rule Venezuela as President through various periods, but above all, he never ceased to be a caudillo. Ironically, Paez himself was the originator of the civic cult of Bolivar. Paez's long political career encountered many challenges, as Venezuela struggled to modernize in the years immediately following independence from Spain. At a given moment in which Paez desperately needed some political legitimacy, he appealed to nationalist notions, and decided to bring Bolivar's remains to Venezuela in 1842 (Bolivar had died in Colombia in 1830). Historians perceive this as a cynical gesture of cold political calculation (Damas, 2003) since Paez had been one of Bolivar's bitter enemies, but it gave Paez substantial political leverage, which allowed him to continue his long political career. Paez's decision to repatriate Bolivar's remains set the standard for banal nationalism disputes to continue in Venezuela for many years to come.

Partly because of this cynicism, Chavez went on to develop a particular dislike of Paez. In his telling of Venezuelan history, Chavez was a traitor (Moreno, 2012). According to this narrative, he miserably betrayed Bolivar. Furthermore, Paez was in league with Venezuela's landed aristocracy, and so, despite being a caudillo, he was not truly a man of the people. Chavez toyed with the idea of removing Paez's remains from the National Pantheon in Caracas, but he eventually desisted from the idea.

Yet, he did go forward in removing Paez from banknotes. Again, this aroused a new dispute, although a minor one. Common Venezuelans have not traditionally cared much about Paez, or any other hero from the Independence War, except Bolivar. But historians and intellectuals do care. In their view, although it is undeniable that Paez was a caudillo, to claim that he was a traitor is an overly simplistic narrative (Andrade, 2017). His relationship with Bolivar was very complex, and Bolivar also had his share of guilt in the fallout. Furthermore, for all his faults, Paez is considered as a relevant modernizer of Venezuela, and in that sense he deserves more respect. Paez was a very fallible figure, so the argument goes, but his image ought to be kept in the banknotes. Apart from Bolivar, Chavez also had great admiration for Ezequiel Zamora, a 19th-century caudillo. Zamora launched a military rebellion that would later derive into the bloody Federal War of 1859-1863. As opposed to Bolivar, 
Zamora is a far more divisive figure in Venezuela. Zamora was a peasant who fought for agrarian reform, but he also comes across as a blood-thirsty revolutionary. Historians have noted that his followers had plans to kill anyone who knew how to read and write (Pino, 2006: 197).

Conservative factions in Venezuela have long repudiated the legacy of Zamora. To many critics, the fact that Chavez continuously eulogized Zamora, seemed to be a confirmation that he was also a fiery revolutionary, and as such, he represented the danger of leading Venezuela into a new civil war, just as Zamora had done (Frontado, 2001).

Although he was happy to promote Zamora as a hero, Chavez never included his image in banknotes. Yet, in 2018, under the Maduro administration, banknotes with his image were printed. By this time, Venezuela's economy had collapsed, and the country was in the midst of a humanitarian crisis. So, given that attention was focused on far more relevant things, few people took issue with this particular banal nationalism dispute. However, especially amongst intellectual elites, the discomfort with Zamora and his representation in banknotes, remains there.

\section{Conclusion}

Analysts of Venezuela's recent crisis have placed great emphasis on economic and political variables. This is certainly justified, given that Venezuela, with its immense oil wealth, is of interest to the dynamics of world powers, such as the United States and Russia.

However, we must not lose sight of the fact that, parallel to that, Venezuela has also been through its own culture war, and this also forms part of the picture. As James Davison Hunter (1992) defined it in his landmark Culture Wars: The Struggle to Define America, a culture war is a conflict between social groups, who dispute the dominance of their views, beliefs, and practices.

In countries such as the United States, this struggle may find expression in topics such as abortion, homosexuality, race, and feminism. During the past 20 years, in Venezuela, these topics have not been at the center of culture wars. Instead, a more central feature of the culture war has been national identity. Venezuela, as with most Latin American nations, is a racially mixed country, so disputes over the ethnic character of the nation are moot.

However, disputes over the civic values of the nation have become far more relevant. And, in this case, nationalist symbols become means of expression over these disputes. Seemingly banal symbols, such as flags, coats of arms, and banknotes, have actually been a micro-cosmos of Venezuela's larger 
confrontations: populism versus elitism, socialism versus capitalism, and authoritarianism versus democracy.

Venezuela has many challenges ahead. This nation must reconstruct its shattered economy, and it must find a solution to the political crisis that has been afflicting it for the past 5 years. However, one frequently neglected challenge is having to come to terms with its own culture wars, and trying to settle the banal nationalism disputes. As I aspire to have proven in this article, these disputes are very relevant, and analysts must not lose sight of them.

\section{References}

Alba Ciudad. 2015. "Venezuela denuncia campaña antivenezolana en medios de Colombia". Alba Ciudad. February 17th. Available at: https://albaciudad.org/2015/02/venezuela-denuncia-campana-antivenezolana-en-medios-de-colombia/

Altez, Rogelio. 2006. El desastre de 1812 en Venezuela: sismos, vulnerabilidades y una patria no tan boba. Universidad Catolica Andres Bello.

Álvarez-Muro, Alexandra. 2016. "Contexto, modelos mentales y topos en la sentencia condenatoria de Leopoldo López”. Discurso \& Sociedad, 10(3), 377-403.

Anderson, Benedict. 2006. Imagined communities. New York: Routledge.

Andrade, Gabriel. 2017. "Paez no es ningun monstruo". Revista de Artes y Humanidades UNICA. 18, 43.

Andrade, Gabriel. 2019. "Conspiracy Mongering in Venezuela: The Chavismo Period (19982018)". Bulletin of Latin American Research. 38, 4.

Angosto-Ferrández, Luis Fernando. 2016. “The afterlives of Hugo Chávez as political symbol". Anthropology Today, 32(5), 8-12.

Aronowitz, Stanley. 2016. The crisis in historical materialism: Class, politics and culture in Marxist theory. Springer.

Arreaza, Irma Chumaceiro. 2003. "El discurso de Hugo Chávez: Bolívar como estrategia para dividir a los venezolanos". Boletín de lingüistica, (20), 22-42.

Avendano, Emily. 2017. "La cara falsa de Bolivar". Climax. July 26th. Available at: https:// elestimulo.com/climax/la-cara-falsa-de-bolivar/

Billig, Michael. 1995. Banal nationalism. New York: Sage.

Cannon, Barry. 2004. "Venezuela, April 2002: Coup or popular rebellion? The myth of a united Venezuela". Bulletin of Latin American Research, 23(3), 285-302.

Carbó, Eduardo Posada. 2012. “Ideas y caudillos”. Economía \& Región, 6(2), 222-224.

Carrasquero, Guillermo Boscan. 2010. "Ceresole y la Revolución de Hugo Chávez: La relación caudillo, ejército y pueblo". Revista de Ciencias Sociales (Cl), (25), 57-73.

Damas, German Carrera. 2003. El culto a Bolivar: esbozo para un estudio de la historia de las ideas en Venezuela. Caracas: Editorial Alfa.

Encarnación, Omar. 2016. “American Caudillo”. Foreign Affairs. May 12. 


\section{Journal of Nationalism, Memory \& Language Politics 14(2)}

Frontado, Antonio. 2001. "El fantasma de Zamora". Libertad digital. March 31st. Available at: https://www.libertaddigital.com/opinion/armando-frontado/el-fantasma-de-zamora-3017/

Garcia Jorge \& Lozano, Daniel. 2012. "La gorra de la polémica”. El mundo. Oct 3. Available at: https://www.elmundo.es/america/2012/10/03/venezuela/1349282078.html

Gellner, Ernest. 1991. "Nationalism and politics in Eastern Europe.” New Left Review 189.5, 127-34.

Grillet, Maria E., Hernández-Villena, J. V., Llewellyn, M. S., Paniz-Mondolfi, A. E., Tami, A., Vincenti-Gonzalez, M. F.,... \& Blohm, G. 2019. "Venezuela's humanitarian crisis, resurgence of vector-borne diseases, and implications for spillover in the region". The Lancet Infectious Diseases.

Hastings, Adrian. 1997. The construction of nationhood: Ethnicity, religion and nationalism. Cambridge University Press.

Hawkins, Kirk. 2003. "Populism in Venezuela: the rise of Chavismo". Third World Quarterly, 24(6), 1137-1160.

Heydra, Pedro. 2003. Las promesas de Chavez. Caracas: Libros de El Nacional.

Hunter, James. 1992. Culture Wars: The Struggle to Define America. New York: Basic.

Kohan, Nestor. 2013. "Bolívar, la guerra social y el pueblo en armas". Cuadernos de Marte, (5), 45-61.

La Nacion. 2013. "Hugo Chávez cambió desde el nombre del país hasta su huso horario". La Nacion. March 6th. Available at: https://www.lanacion.com.ar/el-mundo/chavez-cambiodesde-el-nombre-del-pais-hasta-el-uso-horario-nid1560742

Limongi, Arnold. 2016. “The New Face Of Simón Bolívar: Hyper-Realism Or Distortion?” The Chicago Chronicle. May 11th. Available at: https://curacaochronicle.com/columns/thenew-face-of-simon-bolivar-hyper-realism-or-distortion/

Marshall, Tim. 2016. Worth Dying for: The Power and Politics of Flags. New York: Elliott and Thompson Limited.

Mejía, Guillermo. 2012. "El rostro de Simon Bolivar. Del” Ars Vera Icono" historico al" Art Virtopsico Icono” 3D-HD”. Geominas, 40(57-58), 27-41.

Moreno, Alejandro. 2012. "El catire Paez vence de nuevo después de doscientos años". Diario exterior. September 9th. Available at: https://www.eldiarioexterior.com/el-catire-paezvence-de-41347.htm

Olins, Wally. 1979. "Corporate Identity-The Myth and The Reality". Journal of the Royal society of ArtS, 127(5272), 208-223.

Pabian, Mark. 2008. "Venezuela: From "third way" to socialist revolution”. Direct Action, 4.

Perdomo, Rogelio. 2007. "Estado y justicia en tiempos de Gómez (Venezuela 1909-1935)”. Politeia, 30(39), 121-150.

Pino, Elias. 2006. El divino Bolivar. Caracas: Alfa.

Plessmann, Antonio. 2002. "Venezuela: oposición y estado de derecho". Revista del Observatorio Social de América Latina, (7).

Podeh, Elieh. 2011. "The symbolism of the Arab flag in modern Arab states: between commonality and uniqueness". Nations and Nationalism, 17(2), 419-442. 
Banal Nationalism Disputes in Venezuela: 1999-2019

Queipo, Edgar, Queipo, Jose, \& de Mora, Diana. 2007. "El centauro llanero. Sus mitos y símbolos en la identidad nacional venezolana”. Opción, 23(53), 91-111.

Ramos, Jorge. 2016. Take a Stand: Lessons From Rebels. New York: Penguin.

Sáez, Ebert Cardoza. 2015. "El caudillismo y militarismo en Venezuela. Orígenes, conceptualización y consecuencias". Procesos Históricos, (28), 143-153.

Sahlins, Marshall. 2013. Culture and practical reason. University of Chicago Press.

Smith, Whitney. 1975. Flags through the Ages and across the World. New York: MacGraw Hill.

Solo Clic. 2014. "Ondean banderas de guerra a muerte en Merida”. Solo Clic. March 10th. Available at: http://www.solo-clic.com/protestas-merida-ondean-banderas-de-guerra-amuerte-en-merida/

Tarver, Michael. 2018. The history of Venezuela. New York: ABC-CLIO.

Telesur. 2016. Ramos Allup insiste en arremeter contra figura de Chávez y Bolívar. Telesur. January 9th. Available at: https://www.telesurtv.net/news/Ramos-Allup-insiste-en-arremeter-contra-figura-de-Chavez-y-Bolivar-20160109-0001.html

Toro, Fernando. 2013. Chavez Wasn't Just a Zany Buffoon, He Was an Oppressive Autocrat. The Atlantic. March 5th, 2013. Available at: https:/www.theatlantic.com/international/ archive/2013/03/chavez-wasnt-just-a-zany-buffoon-he-was-an-oppressive-autocrat/273745/

Torres, Ana Teresa. 2009. La herencia de la tribu: del mito de la independencia a la Revolución Bolivariana. Caracas: Editorial Alfa.

Turner, Victor. 1975. “Symbolic studies." Annual Review of Anthropology 4.1 (1975): 145-161.

Welch, Michael, \& Bryan, Jennifer. 1996. "Flag desecration in American culture: Offenses against civil religion and a consecrated symbol of nationalism". Crime, Law and Social Change, 26(1), 77-93.

Weyland, Kurt. 2013. Latin America's authoritarian drift: the threat from the populist left. Journal of democracy, 24(3), 18-32. 